\title{
The Effect of Utilizing Digital Storytelling on Developing Oral Communication Skills for 5th Grade Students at Rafah Primary Schools
}

\author{
Ayman Hassan Ahmad Abu Elenein \\ Assistant Professor, Curriculum and English Teaching Methods, Al-Aqsa University of Gaza, \\ Palestine \\ ahae 23@hotmail.com
}

\begin{tabular}{l|l}
$\begin{array}{l}\text { Received: } \\
\text { 23/05/2019 }\end{array}$ & \begin{tabular}{l}
\multicolumn{1}{c}{ Abstract } \\
The study aimed at identifying the effect of utilizing digital storytelling \\
on developing oral communication skills for 5th grade students at \\
Rafah Primary schools. It adopted quasi-experimental approach. \\
Two tools are used to collect data; a checklist of oral communication \\
25/06/2019 \\
skills and a pre-post achievement test. To analyse data, the \\
Keywords: \\
$\begin{array}{l}\text { Communication Skills, } \\
\text { Digital Storytelling, }\end{array}$ \\
Effect, Oral, Primary \\
deviation, t-test and anova. The study revealed many findings that \\
there was a positive effect of digital storytelling on developing oral \\
communication skills. The study also recommended that digital \\
storytelling should be used to develop students' oral performance at \\
primary and secondary schools.
\end{tabular} \\
\hline
\end{tabular}

1. INTRODUCTION

The English language includes a variety of learning aspects. Oral communication (OC) acts as the most important aspect of English language to express thoughts, hopes, ambitions, and daily actions. Moreover, it is known that effective communication comes out of interactive relationships which reflect an essential part of daily life, especially in education. For this reason, storytelling (ST) can be implemented to foster the capacity of teaching and learning processes as primary school pupils learn better with stories. Stories are refreshers. When a teacher says, "Let's listen to a story," pupils brisk and smile. Even difficult subjects can be taught easily through stories.

Referring to some Arab education systems such as the Egyptian education system and its relation to English as a foreign language (EFL) teaching and learning, Latif (2017) states that the status of English in Egyptian schools has changed from an optional subject to a compulsory one. Most school children speak Arabic as their first language, English as second and French or German as their third or foreign language. Generally speaking, the link between knowledge of English and success in the changing Palestinian environment and in the global economic community has resulted in a growing demand for English language proficiency among individuals, sufficient enough to meet the new societal and global market needs (Akkari, 2004). Despite many large scales, Ministry of Education (MOE) initiatives to change language pedagogy in the Palestinian context, most classrooms and schools remain unchanged and evidence of improvement is still limited (Ginsburg, 2010). For example, with respect to adopting communicative language teaching approaches as a way of improving the English language teaching and learning practices. Concerning the primary education, Juraid and Munawrah (2016) state that English as a global language has spread in primary schools in many non-English speaking countries. In addition, Thapa et al. (2013) argue that pupils can 
learn literacy skills through instruction and practice of speaking, reading, writing and listening. Oral communication is a way of exchanging information through the sense of hearing and making meaning of what was practiced. Schady (2011) stated that childhood period is the most rapid period of development in human life. Some children may develop at their own pace but most children progress through an identifiable sequence of physical, cognitive, social and emotional growth and change.

Moving to oral communication, Jalongo (2008) assures that oral communication prepares young children for later better learning. On the other hand, Raghavendra, Olsson, Sampson, Mcinerney, and Connell (2012) submitted that it is crucial for a child to develop good communication skills in order to cope with the academic demands of school to learn adequate literacy skills. In the same line, Ahern, Bermejo, and Fleta (2008) declare that Oral Communication Skills (OCSs) were usually placed ahead of work experience, motivation, and academic permits as criteria for new recruitment for employment.

Communication skills help children guide their self-inquiry and discover their individual possibilities. Mostafa (2017) states that children who are active communicators can incorporate the things they hear, chants and short stories, faster in their framework of knowledge than a more passive counterpart. In his own view, Tramel (2011) observes that Children can also exhibit better concentration and memory when they develop good communication. Shiel, Cregan, McGough, and Archer (2012) explain that oral communication is the child's first, most important, and most frequently used structured medium of communication.

In addition, and most significantly, oral communication is the primary mediator of culture, the way in which children locate themselves in the world. Basically, oral communication is about communicating with other people. It involves a process of utilizing knowledge and skills in order to listen and speak effectively. Although the curriculum, as Ferrari, Punie, and Redecker (2012) assert, places a strong emphasis on oral communication, it has been widely acknowledged that the implementation of the Oral communication strand has proved challenging and some teachers may have struggled to implement this component because the underlying framework was unclear to them. Children, as beginners, may face many communication problems. Salmon (2017) reveals that around half of children enter schools with a lack of communication ability. Lindsay et al (2010) declare that the reasons for such poor communication include families with lower socioeconomic status, children with hearing loss, brain injury, learning disabilities and for some, the cause is unknown. Nowadays educational institutes are constantly developing new techniques for sounds, pictures, and prints. ST is used as the most basic level of communication- person-to-person. Patil (2008) asserts that building up the learner's performance was a priority that the teacher should consider in order to make the learner feel comfortable with their language use. Songsiri (2007) assures that OCSs could be developed from appropriate syllabus design, methods of teaching, and sufficient tasks and materials which are included in ST.

Widodo (2016) mentions that as Teaching English to Young Learners (TEYL) continues to flourish, research into this area has begun to grow. Despite this, there remains a lack of classroom-based studies in English as a foreign language (EFL) context. Werner (2011) suggests using one of the participatory activities such as DST for improving OCP. In addition, young learners interact with technology such as digital stories to learn English or how they work multimodal texts such as digital stories. In addition, if children are engaged effectively, there will be a great potential for creativity, and a passionate commitment to things which interest them. Tatum (2009) argues that almost nothing more exciting than a class of involved young people at this age pursuing a learning goal with enthusiasm as it happens in DST. Therefore, student's engagement must be provoke with material which is relevant and involving. At the same time, we need to do what we can to bolster our pupils' 
self-esteem and be conscious of their need for identity.In this respect, the researcher suggests that DST can be one of those activities/strategies which encourage pupils to learn and practice English. DST is an aspect of oral communication which encourages young learners to be active during the learning process. It is not a one-way act as there are usually at least two people involved, a teller and a listener. Norrick (2000) declares that DST provides familiar things to children and creates an active interaction amongst pupils. If a topic is difficult to explain to children, we can integrate the topic into a story. DST presents the solution which might help children to visualize the textbooks and understand them better.

In this study, to engage pupils in meaning making-oriented English learning, DST is introduced because this category is rarely taught in Palestinian primary schools, and it is a new strategy suggested to be included in Palestinian English curricula. In the context of primary schools, DST helps to share knowledge, wisdom, morals and cultural values. With this in mind, teachers may be encouraged to include stories in their language classrooms.

\subsection{Statement of the Problem}

The results obtained from the pilot study reveal that EFL primary stage pupils in Ibn Sina Primary School lack the ability to communicate orally. The pupils have no much exposure to oral English in class. Both teachers and pupils depend on the Arabic language as a means to communicate inside the class and they mostly rely on Arabic. Moreover, the teachers adopted a narrow view of teaching as a job,not a message to be delivered from a generation to another. Furthermore, the English language is taught and learned for the sake of passing examinations, not for developing OCP. So, pupils may perform poorly, as a result, they may dislike English classes. Consequently, pupils can understand neither native speakers nor their local teachers.

\subsection{Objectives of the Study}

This study aimed at:

1- Identifying the oral communication skills necessary for fifth year EFL primary school pupils.

2- Determining the methods of measuring digital storytelling in TEFL in the primary stage.

3- Designing the outline of teaching storytelling to develop the fifth-year primary pupils' EFL oral communication skills, identifying and measuring the pupils' oral communication skills.

\subsection{Research Questions}

This study investigated the following main question:

What is the effect of utilizing DST on developing the primary school pupils' EFL OCS?

The main question is divided into the following sub-questions:

1. What are the EFL OCSs necessary for the primary school pupils?

2. To what extent do the primary school pupils have the required EFL OCSs?

3. What are the characteristics of a suggested strategy based on DST for developing the primary school pupils' English OCSs?

\subsection{Research Hypotheses}

Based on the research questions, the following five hypotheses were tested:

1. There is a statistically significant difference $(\alpha \leq 0.05)$ between the mean score of the experimental group (taught by DST) on the pre-post oral communication test, in favor of the latter.

There is a statistically significant difference $(\alpha \leq 0.05)$ between the mean score of the experimental group (taught by DST) and that of the control group (taught by traditional ST) in the post-test of oral communication.

\subsection{Limitations of the Study}

The study was delimited to: 
1. The population of the study consisted of two groups; experimental and control group $(n=30$ for each) of 5th grade pupils at Ibn Sina primary school. The researcher chose the primary school pupils because they, at this age, tend to be more active and their years of initiative study of EFL would have shaped them into sensitive listeners to stories.

2. Stories from the pupils' textbook told digitally.

3. The first semester of the academic year of $(2018-2019)$

4. Using DST as a teaching strategy.

5. Developing the English OCSs (listening and speaking) of primary five grade students.

\section{LITERATURE REVIEW}

\subsection{English Oral Communication}

Unless the pupils are remaining and are immersed in an English-communication environment, the real understanding and use of English is slight. In this respect, Bandung and Langi (2011) state that the English language is used for practicing meaningful communication. Similarly, García (2011)declares that the best way to learn a foreign language is the constant involvement in real situations so as to communicate easily with others. Consequently, this view has been receiving a considerable support widely. For example, Koşar and Bedir (2014) explain that learners' communication performance is an important category to be improved to make the learners conduct communication directly. In the same vein, Razmjoo and Ghasemi (2011) reveal that the teacher's effort in proposing learners to articulate their ideas and opinions are highly expected. Therefore, Boonkit (2010) assures that communication performance became an important goal in the teaching and learning process.

Similarly as stated by Atta-Alla (2012), the integration of language skills is best accomplished by engaging pupils in practicing communicative language learning activities. Participation in such activities promotes language integration. Pupils' communicative skills are improved by interacting with each other in a meaningful way. It is clear that "Language and Communication Approach" enhances the pupils' communicative skills. However, being submerged in an authentic environment and being able to cooperate with classmates is not enough to learn a new foreign language. As a result, Graham (2007) claims that many of learners try to focus on their speaking rather than other skills. Numerous numbers of language learners have been emphasizing their attention in mastering speaking competence. Therefore, most learners believe that the important goal of learning English is how to be able to sustain the flow of conversation orally.

By mastering this skill, as Rohmah (2012) explains, learners can actively get involved in the run of conversation as well as reciprocate the information with others. And this what exactly happens when pupils are involved in ST activities. Keiling (2010) claims that there are some other cases of communication includes the use of signing and ST. In this study, the researcher is concentrating on oral communication skills which refer to the use of DST. The process of oral communication is concerned with DST. Thus, this research aims to enable children learn how to express their thoughts so that listeners can understand easily and learn how to improve their communication skills through DST.

\subsection{Essential Factors of Learning OCSs}

In order to have a successful conversation, a series of oral skills should be learned by children. Yelland, Lee, and O'Rourke (2008) have shown five essential factors for children learning OCSs: attention and listening vocabulary, building sentences, ST, and conversations. Although this classification refers to the whole range of communication skills, verbal skills receive much more attention than non-verbal.

\section{Oral Communication in Primary School}

Primary National Strategies ( 2009) assure that excellent teaching of listening and speaking enhances children's learning and raises standards further. 


\section{Listening:}

- develops phonological skills, particularly phonemic awareness in learning familiar and unfamiliar sounds;

- links sound with mime, gesture and facial expression, which consolidates meaning and brings language to life;

- extends children's understanding of how speakers of different languages use gesture, volume, and intonation;

\section{Speaking:}

Talk is the underlying key factor in the development of literacy. In learning a new language pupils reproduce sounds, create phrases and sentences, and engage in simple conversations. The learning of a new language:

- makes pupils aware that different languages have different sounds (Spanish 'j', German 'ich/ each' and French 'r') which widen learners' linguistic repertoire;

- makes pupils learn about the importance of pronunciation and intonation and formal and informal use of language;

- develops pupils' awareness of the need for clear and specific pronunciation to achieve successful communication.

\subsection{Commentary}

The above literature gives an overview of the process of child communication development, especially in the primary stage. The aspects of oral communication for children have been explained and an exploration of these will offer an insight into what factors can influence children, in terms of interpersonal communication. The demands of oral communication may, however, be treated differently by teachers in school. Learning communication is not limited to a single curriculum but should be included in all aspects of every curriculum.

In primary schools, as Ying (2012) asserts, children are developing communication skills, especially in English. Educational researchers and teachers show their interests in exploring how to meet these children's needs so that they still have a chance to achieve normal development or at least resolve some of these problems. Lin and Wu (2010) declare that English language education in elementary school aims to provide pupils with the opportunity to develop their communicative competence. However, when using a traditional teaching model, teachers continually ask children to memorize words and grammar, furthermore, they have the children do more than enough homework every day. This gives pupils a dislike for English; thinking and learning English then becomes a difficult and boring thing, andfinally, the children would tend to lose any motivation to learn English. Hence, this study used T/DST to motivate children to learn English and develop their OCP.

\subsection{Digital Storytelling (DST)}

\section{What is Digital Storytelling (DST)?}

Mcquiggan, Rowe, Lee, and Lester (2008), state that the DST software programs are further classified into vocabulary, attention and listening, building sentences and DST according to the functional design and learning aims:

Vocabulary: the teacher can use some educational games to assist children in recognizing synonyms. 
Attention and listening: the teacher can ask children to listen to sounds from a city or rural environment and then guess what is making the sounds.

Building sentences: the teacher can ask children to put some pieces of words together in the correct order, so as to form a sentence. This enables children to use correct conjunctions, to join two simple sentences into a complex sentence.

Storytelling: This is important in delivering news, sharing information and talking about our feelings, in the communication process (Yelland et al., 2008). In the area of educational DST software, ST exists to ask children to create, rather than simply listen to or read a story.

\subsection{Advantages of DST}

Basically, as Siemens (2014) assumes, there are many benefits which have been widely accepted for the use of educational DST software in schools. Educational DST software is capable of producing a stimulating learning process. Daigle (2008) explored the psychological perspective, engagement, which is driven by curiosity, interest, and enjoyment, is an inner motivation for learning. An engaged learner, as Widodo (2016) assumes, would like to achieve their personal or intellectual goals.As Vinogradova (2011) suggest, technology can help pupils create and tell stories. Ying (2012) explores the experience of using DST which is associated with the pupil's mental state and concludes some interesting points regarding engagement strategies:

1. A challenging situation can engage learners. Thus, users already have some clues but they still need some skills or to take some risks, to reach a goal.

2. Dynamic situations can draw users' attention. A scene which contains rapid change and movement activities, such as animation, can attract users' interest, especially that of children.

3. Control of the computer ST application can have great effects on the users' engagement, either in education or commercial games, employ this strategy to arouse user interest.

4. Blending learning content into a story, as done by the researcher in 2017 can be an engaging way of learning. In the conventional classroom, teachers often use a story to set the scene and then discuss the social, emotional and behavioral issues, which are involved in the story.

\subsection{DST in Developing Oral Communication}

Afrilyasanti and Basthomi (2011) assured the role of DST in the enhancement of EFL learners' oral production. Al-Mousawi and Alsumait (2012) found that the learners were able to present their stories intelligibly and also through a smooth and spontaneous speech flow. By telling and retelling their stories, learners had many opportunities to practice their pronunciation. Furthermore, learners could assess their own fluency by listening to their recorded voices.

\subsection{DST as a Motivating Tool for Learning}

DST is considered to be an effective instrument to boost learners' motivation to learn languages and increase their active participation in the language learning process through content, pedagogy and learning skills. This issue was examined in one of the recent studies in the field. Yang and Wu (2012) investigated the effects of DST on the motivation of one hundred and ten grade ten EFL learners. Results indicated that the participants in the experimental group outperformed the control group in all the three groups of variables measured: learning motivation, creative thinking and language skills. In the same vein, Lucarevschi (2016a) assured the role of DST in motivating a group young learners to learn EFL.

\subsection{Educational Benefits of Integrating DST}


Some empirical studies show that DST enhances learner-centered learning and build a learner community of practice. Equally important, when working on DST, learners engage in "the story making and sharing process" (Lee, 2014, p. 339). This social engagement creates a supportive learner-centered learning environment. As DST, an emerging genre offers many educational benefits as discussed earlier, digital stories have received increasing attention from language practitioners. The use of DST has been well documented in the educational domain, particularly in the context of ESL and EFL programs. In the context of early age education, Swan and Hofer (2013) investigated how eighth graders in a history class created documentaries. The pupils showed enthusiasm for the filmmaking task and felt motivated and showed creativity in making the films.

\subsection{Related Studies}

The study of Widodo (2016) was implemented in two primary schools in Banyuwangi, East Java, Indonesia. The nature of the study was participatory action research used DST as a tool for learning English through creation and presentation of digital stories. The participants were 60 children between the ages of 10 and 12 years old from two government-managed primary schools. The results of the study indicated that pupils learned to understand a story in terms of functions and meanings, use technology to create stories, deploy both Bahasa Indonesia and English as semiotic tools for story production, and to engage in multimodal tasks.

The study of Abdolmanafi-Rokni (2014) investigated the effect of two ways of ST on speaking skills of Iranian EFL learners. The traditional way of ST which is called ST aloud is performed by a teacher or a narrator in an educational setting. Another way of ST named DST is done using the internet and websites. This mixed method study measured the differences between the effect of DST and ST on speaking skill of Iranian EFL learners using both qualitative and quantitative methods. The data were collected from 42 pupils who were aged19 to 25 years old at Payam Noor University in Gorgan, Iran. In this study, a TOEFL speaking test was administered to pupils in two classes as the pre-test. Next, one of the classes as an experimental group consisting of 21 participants were exposed to treatment in which they participated in a DST course for 12 sessions. The other class as the control group had the traditional ST instruction. At the end of the course, the same TOEFL speaking test was administered to both groups. Alongside the speaking test, the experimental group was given a questionnaire about the effectiveness of DST course on their motivation to improve their speaking ability. Concerning the results, the data analyzed by using SPSS software proved the efficiency of the DST on the oral performance of EFL learners.

The study of Eman Mohamed and Hasnaa Sabry (2014) investigated the effectiveness of using DST and Weblogs instruction in enhancing EFL narrative writing and critical thinking skills among EFL majors at Faculty of Education. The design of the research is one group pre-posttest. The sample of the research consisted of forty third-year EFL majors, at Faculty of Education, Benha University, Egypt. The research sample was engaged in certain activities such as ST, journal writing, personal diaries and reflection Weblogs. The instruments of the research included an EFL narrative writing questionnaire; an EFL narrative writing test; an EFL critical thinking questionnaire; an EFL critical thinking scale and interview prepared by the researcher. The instruments were applied to the sample of the research before and after implementing the program. Results of the research revealed that there is a statistically significant difference between the mean scores of the study sample in the pre and post assessment of EFL narrative writing and critical thinking skills in favor of the post-assessment.

The study of Lee (2014) explored how the use of digital news stories promoted the development of content knowledge and oral language skills. The study involved 15 advanced Spanish pupils who used Voice Thread, an interactive multimedia tool, to create and 
exchange digital news regarding current events over the course of one semester. Both quantitative and qualitative data collected from post-surveys, transcribed digital recordings, blog reflections, and final interviews were analyzed. The results showed that digital news empowered pupils to use their own voices for self-expression and self-reflection and that social interaction helped establish a sense of community in which pupils supported each other by offering new ideas and feedback on each other's writing. In addition, pupils gained multiliteracy skills and further improved their speaking fluency. The findings also suggest that well-designed tasks are vital and that the instructor's guidance is needed to facilitate critical reflection.

The study of Ono (2014) explored the effect of a Project-based learning (PBL) approach to making academic digital stories in a Japanese EFL presentation course and show the effectiveness under 'one-to-one' computer-assisted language learning (CALL) settings. Foreign language anxiety in the classroom, especially which in speaking, deprives learners, especially less proficient learners, of their learning attitude and development. Making digital stories have been shown to have an effect on cognitive development, self-authoring and other academic as well as linguistic skills. The purpose of the study was to show the effectiveness of PBL movie presentation in 'one-to-one' computer-assisted language learning (CALL) settings. Data from two groups with different proficiency levels, following the same syllabus, were dynamically compared in terms of foreign language anxiety and awareness of PBL skills. The data included pre- and post-test scores of questionnaire research on PBL skills and foreign language anxiety, in addition to open-ended feedback. These results encouraged the researcher to suggest that our PBL approach presented in this study to digital movie presentation is naturally incorporated in an EFL presentation course for two distinct purposes: to reduce foreign language anxiety for less proficient learners and to foster PBL skills like deeper thinking and reflection for learners with higher proficiency.

In the study of Razmi, Pourali, and Nozad (2014), the results of an investigation of the use of DST in an Iranian undergraduate EFL classroom was explored among sixty learners to see whether using computer-based tools affect the improvement of learners' narrative skills. Participants were divided into two groups and took part in an activity organized by researchers. One group created their digital stories of the given stories selected from Perrine's literature course book to be presented in the classroom. Other group was asked to read the given stories and then present them. Both groups were tested for their oral production and competence. The results showed that by the use of DST techniques pupils develop better oral skills and this technique can be considered as an essential tool in foreign language learning and teaching.

The study of Smeda (2014) investigated the pedagogical aspects of DST and the impact of DST on student learning when teachers and pupils use digital stories. The study developed a new e-Learning DST (eldest) framework. This framework was based on the needs and capabilities of learners at various stages of learning. A multi-site case study was conducted in one Australian school at primary and secondary levels. In selected classrooms, pupils and teachers had the opportunity to engage in innovative learning experiences based on DST. Data were collected with qualitative and quantitative methods. Rubric evaluation was used to collect quantitative data. Data collection was based on mixed methods research to evaluate if and how DST enhances teaching and learning outcomes. The findings from this study suggest that DST is a powerful tool to integrate instructional messages with learning activities to create more engaging and exciting learning environments.

\section{THE RESEARCH METHODOLOGY}

The present study used the quasi-experimental design to detect the effect of using DST to develop the English OCS of primary fifth pupils at Ibn Sina primary school. Two groups were selected to represent the sample of the study; the experimental group $(n=30)$ and the 
control group $(\mathrm{n}=30)$. The whole experiment from beginning to the end lasted for four weeks. The results of the pre-post tests were analyzed using a t-test for independent samples to investigate if there was any significant difference between the mean scores of the two groups and between the pre-posttest for each group as well.

\subsection{Procedures of the Study}

To answer the questions of the study and to verify the credibility of its hypotheses, the following procedures were attempted.

1. Reviewing literature and relevant studies related to digital storytelling, oral communication skills and performance, and primary school pupils ${ }^{6}$ characteristics to determine the appropriate measurement of oral communication skills.

2. Submitting the list of the oral communication skills checklist and the oral communication skills pre-posttest to an EFL jury to validate them.

3. Identifying the most appropriate oral communication skills, the semi-structured interview items, pre-posttestcontent according to the jury's comments and opinions.

4. Conducting the modifications of the jury members (if any).

5. Constructing the final version of the oral communication skills checklist for Administration.

6. Constructing an oral communication skills test according to the predeterminedskills categories.

7. Presenting the test to an EFL jury to be validated according to the panel of jury's opinions.

8. Administering the test to another sample of students to determine their reliability.

9. Pre-administering the test to the samples of the two groups.

10. Administering digital storytelling to the experimental group.

11. Post-administering the oral communication skills test to the two experimental and control groups to detect the improvement, if any.

12. Comparing the pre to the post administrations results of each group.

13. Comparing the post-administration results of the groups.

14. Gathering data and then analyzing them statistically.

15. Discussing and interpreting the results in light of the research hypotheses.

16. Drawing conclusions, providing recommendations and suggestions for further research.

\subsection{Population and Sample of Study}

The population of the study consisted of 60 pupils from the fifth grade at Ibn Sina primary school in the second term ( 2018 - 2019). They were divided into two groups: the first

experimental group $(n=30)$ and the second control group $(n=30)$. The first experimental group was taught using the DST to improve their English OCS and the second control group was taught by traditional ST to improve their English OCS. The following table shows the distribution of the participants.

Table 1.The distribution of the sample according to the groups

\begin{tabular}{|c|ccc|}
\hline Group & Experimental group & Control group & Total \\
\hline No & $\mathbf{3 0}$ & $\mathbf{3 0}$ & $\mathbf{6 0}$ \\
\hline
\end{tabular}

\section{Controlling the variables relevant to the participants:}

To assure the results' accuracy and avoid any marginal interference, the groups were randomly chosen from a purposive sample (60 from $5^{\text {th }}$ graders) from Ibn Sina primary school where the researcher works by using the following procedures: 
- The sample was filtered by drawing out pupils who havehearing impairment.

- The researcher divided the sample into two groups by choosing the individual numbers for the first experimental group and the even numbers for the second control group to avoid bias.

- The researcher tried to control some variables before applying the study:

1- Age variable: The researcher recorded the pupils' ages from their school files at the beginning of the school year (2017-2018)

2- Determining the equivalence between the two experimental and control groups:

-To make sure that the sample subjects are equivalent in their previous English language achievement, the researcher applied the pre- achievement test. The results of the subjects were recorded and statistically analyzed by using T-test. Table (2) shows the mean and the standard deviation of each group in English previous learning. The results analysis indicates that there are no statistically significant differences between the first experimental group and the second control groups at (0.05) level.

Table 2. T-test results of English achievement controlling variable

\begin{tabular}{|c|c|c|c|c|c|c|}
\hline Skills & $\begin{array}{c}\text { The pre- } \\
\text { administration }\end{array}$ & $\mathrm{N}$ & Mean & $\begin{array}{c}\text { Standard } \\
\text { deviation }\end{array}$ & $\begin{array}{c}\text { Critical } \\
\text { value }\end{array}$ & Significance \\
\hline $\begin{array}{c}\text { skills as a } \\
\text { whole }\end{array}$ & $\begin{array}{c}\text { The first } \\
\text { experimental group }\end{array}$ & 30 & 22.50 & 5.40 & 0.075 & $\begin{array}{c}\text { Insignificance } \\
\text { at } \mathbf{0 . 0 5}\end{array}$ \\
\cline { 2 - 4 } & $\begin{array}{c}\text { The second control } \\
\text { group }\end{array}$ & $\mathbf{3 0}$ & $\mathbf{2 2 . 4 0}$ & $\mathbf{4 . 8 7}$ & & \\
\hline
\end{tabular}

Table (2) points out that there are no statistically significant differences between the mean scores of the first experimental and the second control group in the pre-administration of oral communication skills as a whole, and this proves that the groups are equal.

4. METHODOLOGY

4.1. The Statistical Analysis

The data were collected and computed by using (SPSS) Statistical Package for social Science Spearman correlation, Alpha Cronbach Technique and Spilt - half Technique were used to confirm the test validity and reliability. On the other hand, T-test was used to measure the statistical differences in mean scores between the first experimental group and the second control group due to the teaching method.

\subsection{Instruments}

The present study made use of the following instruments:

1. The OCSs checklist.

2. A pre-posttest for assessing pupils' EFL OCSs which are:

1- Listening 2- Speaking

5. RESULTS AND DISCUSSION

The results related to the main question "What is the effect of digital storytelling on developing the primary school pupils' EFL oral communication skills?"

In order to answer this question, the following hypotheses were phrased to be verified:

1- There is a statistically significant difference $(\alpha \leq 0.05)$ between the mean score of the experimental group (taught by digital storytelling) on the pre-post oral communication test, in favor of the latter.

2- There is a statistically significant difference $(\alpha \leq 0.05)$ between the mean score of the experimental group (taught by digital storytelling) and that of the control group 
(taught by traditional storytelling) in the post-test of oral communication in favor of the experimental group .

Table 3. OCSs Percentage and Relative weight

\begin{tabular}{llll}
\hline No. & OCSs of $\mathbf{5}^{\text {th }}$ primary graders & $\begin{array}{l}\text { Percentage } \\
\text { ofeach skill }\end{array}$ & $\begin{array}{l}\text { Relative } \\
\text { Weight }\end{array}$ \\
\hline 1 & Listening to identify the keywords of a story & $91.6 \%$ & 10.4 \\
\hline 2 & Listening and repeating sentences in a story & $83.3 \%$ & 9.5 \\
\hline 3 & Listening and answering some questions in a story & $83.3 \%$ & 9.5 \\
\hline 4 & Listening to and rearranging the parts of a story & $83.3 \%$ & 9.5 \\
\hline 5 & Introducing him/herself & $91.6 \%$ & 10.4 \\
\hline 6 & Describing some pictures of a story & $91.6 \%$ & 10.4 \\
\hline 7 & Playing a character's role in a story & $83.3 \%$ & 9.5 \\
\hline 8 & Retelling parts of a story & $91.6 \%$ & 10.4 \\
\hline
\end{tabular}

Table 3 shows that the relative weight of each oral communication skill is high. Therefore, it could be concluded that these ten creative reading skills are applicable to the study participants.

\section{Findings:}

After validating the checklist, it was concluded that there were eight English OCSs to be valid, very important and required for the fifth year EFL primary pupils. Consequently, those skills were used as a basis for the pre-post OCSs test. They are as follows:

1. Listening to identify the keywords of a story

2. Listening and repeating sentences in a story

3. Listening and answering some questions in a story

4. Listening and rearranging the parts of a story

5. Introducing him/herself

6. Describing some pictures of a story

7. Playing a character's role in a story

8. Retelling parts of a story.

\section{Verifying the First Hypothesis:}

The first hypothesis:

"There is a statistically significant difference $(\alpha \leq 0.05)$ between the mean score of the experimental group (taught by digital storytelling) on the pre-post oral communication test, in favor of the latter".

The following table points out the results reached:

Table 4. the results of the pre and post measurement of the first experimental group pupils on the skills test as a whole

\begin{tabular}{lllll|l|l|l|}
\hline & $\begin{array}{l}\text { The experimental } \\
\text { group }\end{array}$ & $\mathrm{N}$ & Mean & $\begin{array}{l}\text { Standard } \\
\text { deviation }\end{array}$ & $\begin{array}{l}\text { t- } \\
\text { test }\end{array}$ & Significance & $\begin{array}{l}\text { Effect } \\
\text { size }\end{array}$ \\
\hline Listening & $\begin{array}{l}\text { The pre } \\
\text { administration }\end{array}$ & 30 & 11.36 & 3.34 & $5.32^{* *}$ & $\begin{array}{l}(0.000<=0.05) \\
\text { sign }\end{array}$ & $\mathbf{0 . 4 6}$ \\
\hline
\end{tabular}




\begin{tabular}{llccccccc}
\hline & $\begin{array}{l}\text { The post } \\
\text { administration }\end{array}$ & 30 & 14.40 & 3.72 & & & Large \\
\hline Speaking & $\begin{array}{l}\text { The pre } \\
\text { administration }\end{array}$ & 30 & 11.13 & 2.73 & $8.44^{* *}$ & $\begin{array}{l}(0.000<=0.05) \\
\text { sign }\end{array}$ & $\mathbf{0 . 6 8}$ \\
$\begin{array}{l}\text { The post } \\
\text { administration }\end{array}$ & 30 & 14.53 & 3.17 & & & Large \\
\hline $\begin{array}{l}\text { Skills as a } \\
\text { whole }\end{array}$ & $\begin{array}{l}\text { The pre } \\
\text { administration }\end{array}$ & 30 & 22.50 & 5.40 & $8.32^{* *}$ & $\begin{array}{l}(0.000<=0.05) \\
\text { sign }\end{array}$ & $\mathbf{0 . 6 0}$ \\
& $\begin{array}{l}\text { The post } \\
\text { administration }\end{array}$ & $\mathbf{3 0}$ & $\mathbf{2 8 . 9 3}$ & $\mathbf{5 . 5 7}$ & & & Large \\
\hline
\end{tabular}

\section{Discussion of Results of the First Hypothesis}

Table 4. points out the following:

There is a clear statistically significant difference between the mean scores of the experimental group (taught by digital storytelling) in the test in favor of the post administering. In addition, T. calculated points out that There is statistical significance which reached (5.32) and it is higher than $\mathrm{T}$. value which reached (1.69) at the significant level of (0.05). This means that pupils' communication performance, in general, has developed due to the experimentation. Also, it can be said that the digital storytelling has a great effect on developing pupil's skills with a doubt degree at the level of (0.05). Table (9) and figure (4) shows that the digital storytelling had a positive effect on developing the overall oral communication skills of the EFL fifth year primary pupils. Therefore, this provides enough evidence to support hypothesis one. According to the referential framework of the effect size, it is apparent that digital storytelling has a large effect size.

\section{Verifying the Second Hypothesis:}

The third hypothesis states that "There is a statistically significant difference $(\alpha \leq 0.05)$ between the mean score of the experimental group (taught by digital storytelling) and that of the control group (taught by traditional storytelling) in the post-test of oral communication.

The following table points out the results reached:

Table 5. The results of the experimental group and control group in the post administration of the communication test as a whole

\begin{tabular}{|c|c|c|c|c|c|c|c|}
\hline & $\begin{array}{l}\text { The post } \\
\text { administration }\end{array}$ & $\mathrm{N}$ & Mean & $\begin{array}{l}\text { Standard } \\
\text { deviation }\end{array}$ & t-test & Significance & $\begin{array}{l}\text { Effect } \\
\text { size }\end{array}$ \\
\hline \multirow[t]{2}{*}{ Listening } & Experimental group & 30 & 14.40 & 3.72 & \multirow[t]{2}{*}{1.33} & \multirow{2}{*}{$\begin{array}{l}(0.189>=0.05) \\
\text { Not } \\
\text { Significance } \\
\text { at } 0.05\end{array}$} & $\mathbf{0 . 0 3 0}$ \\
\hline & Control group & 30 & 13.16 & 3.44 & & & Low \\
\hline \multirow[t]{2}{*}{ Speaking } & $\begin{array}{l}\text { Experimental } \\
\text { group }\end{array}$ & 30 & 14.53 & 3.17 & \multirow[t]{2}{*}{$3.01 * *$} & \multirow{2}{*}{$\begin{array}{l}(0.004>=0.05) \\
\text { Significance } \\
\text { at } 0.05\end{array}$} & 0.15 \\
\hline & Control group & 30 & 12.43 & 2.12 & & & Large \\
\hline \multirow[t]{2}{*}{$\begin{array}{l}\text { Skills as } \\
\text { a whole }\end{array}$} & $\begin{array}{l}\text { Experimental } \\
\text { group }\end{array}$ & 30 & 28.93 & 5.57 & \multirow[t]{2}{*}{$2.50 *$} & \multirow{2}{*}{$\begin{array}{l}(0.015>=0.05) \\
\text { Significance } \\
\text { at } 0.05\end{array}$} & 0.11 \\
\hline & Control group & 30 & 25.60 & 4.70 & & & average \\
\hline
\end{tabular}




\section{Discussion and Interpretation of Results of the Second Hypothesis}

- Table (4) demonstrates that the pupils' mean score in the experimental group of the listening skills as a whole is (14.40), whereas the pupils' mean scores in the control group of the listening skills as a whole are (13.16). So, the pupils' mean score in the experimental group was higher than their mean score in the control group. Speaking

- Skills:

- Table (4) and figure (1) clarifies that the pupils' mean score in the experimental group of the speaking skills as a whole is (14.53) whereas the pupils' mean scores in the control group of the speaking skills as a whole are (12.43). So, the pupils' mean score in the experimental group was higher than their mean score in the control group.

- Oral communication skills as a whole:

- Table (4) and figure (3) show that the pupils' mean score in the experimental group of the oral communications as a whole is (28.93), whereas the pupils' mean scores in the control group of the oral communication as a whole are (25.60). So, the pupils' mean score in the experimental group was higher than their mean score in the control group.

\section{CONCLUSIONS}

Based on the results of this study, the following could be concluded:

1. The results of the study proved that the use digital storytelling develops the experimental group fifth year EFL primary pupils' oral communication skills and performance.

2. Using digital storytelling motivates pupils of fifth year primary pupils to learn more actively to communicate creatively and how to get involved into the daily oral communication. Depending on digital storytelling learning strategies through the study administration steps proved to be effective in enhancing and developing the EFL oral communication skills and performance and enabled the pupils to get involved orally into learning process.

3. Through practicing digital storytelling strategies, the experimental group pupils were encouraged to participate actively through listening to the stories and retelling parts of them as they were motivated to practice various processes such as:

- listening to identify the keywords of a story;

- listening and repeating sentences on a story;

- listening and answering some questions on a story;

- listening and rearranging the parts of a story correctly;

- introducing him/herself;

- describing some pictures of a story;

- playing a character role in a story;

- retelling parts of a story.

\section{Recommendations}

Based on the results of the present study, the following recommendations can be made:

- Storytelling/digital storytelling should receive more attention in teaching especially in the primary education.

- Placing more emphasis on developing pupils' oral communication skills.

- Employing digital storytelling strategies and activities while teaching young learners.

- Taking the EFL oral communication skills and techniques into account while designing English language curricula due to their role in motivating the pupils to get involved in the learning process. 
- Defining the pupils' ability to communicate orally through using stories.

- Reconsidering the teacher in-service training programs and workshops to give more emphasis to communicate orally with pupils creatively.

- Paving the way for pupils to express and share their own ideas and opinions freely and in a communicative manner while EFL lessons as it gives equal opportunities for them to share their language with their classmates and their teachers.

\section{References}

Abdolmanafi-Rokni, S. J. (2014). Digital Storytelling in EFL Classrooms: The Effect on the Oral Performance. International Journal of Language and Linguistics, 2(4), 252-257. https://doi.org/10.11648/j.ijll.20140204.12

Ahern, A. K., Bermejo, M. L. G., \& Fleta, T. (2008). Holistic Learning Through Stories: Children's literature in the EFL classroom. ELT in Primary Education, 98-103.

Akkari, A. (2004). Education in the Middle East and North Africa: The current situation and future challenges. International Education Journal, 5(2), 144-153.

Al-Mousawi, Z., \& Alsumait, A. (2012). A digital storytelling tool for Arab children. In Proceedings of the 14th International Conference on Information Integration and Web-based Applications \& Services (pp. 26-35). ACM.

Atta-Alla, M. N. (2012). Integrating language skills through storytelling. English Language Teaching, $5(12), 1$.

Bandung, Y., \& Langi, A. Z. R. (2011). Implementing ICT in primary schools in Keerom-Papua. In Telecommunication Systems, Services, and Applications (TSSA), 2011 6th International Conference on (pp. 111-114). IEEE.

Boonkit, K. (2010). Enhancing the development of speaking skills for non-native speakers of English. Procedia-Social and Behavioral Sciences, 2(2), 1305-1309.

Eman Mohamed, A.-H., \& Hasnaa Sabry, A.-H. A. H. (2014). Using digital storytelling and weblogs instruction to enhance EFL narrative writing and critical thinking skills among EFL majors at faculty of education. International Research Journal, 5(1), 8-41. https://doi.org/http:/dx.doi.org/10.14303/er.2014.011

Ferrari, A., Punie, Y., \& Redecker, C. (2012). Understanding Digital Competence in the 21 st Century: An Analysis of Current Frameworks. In 21st Century Learning for 21st Century Skills (pp. 7992). Springer. https://doi.org/10.2791/82116

García, O. (2011). Bilingual education in the 21st century: A global perspective. John Wiley \& Sons.

Ginsburg, M. (2010). Improving educational quality through active-learning pedagogies: A comparison of five case studies. Educational Research, 1(3), 62-74.

Good, N., \& Guide, P. (2016). A Balanced Approach to Literacy Development in the Early Years, (March).

Graham, S. (2007). Learner strategies and self-efficacy: Making the connection. Language Learning Journal, 35(1), 81-93.

Hayes, D. (2016). Fallacies affecting policy and practice in the teaching of English as a foreign language in state primary schools in Asia. Asia Pacific Journal of Education, 1-14. 
Hur, J. W., \& Suh, S. (2012). Making learning active with interactive whiteboards, podcasts, and digital storytelling in ELL classrooms. Computers in the Schools, 29(4), 320-338.

Jalongo, M. R. (2008). Beyond a pets theme: Teaching young children to interact safely with dogs. Early Childhood Education Journal, 36(1), 39-45.

Juraid, R. A., Ibrahim, M. M. A., Methods, T., \& Munawrah, M. (2016). The effect of storytelling on developing communication skills of efl female students and their attitudes towards it, 5 (November).

Khamkhien, A. (2011). QUANTITATIVE AND QUALITATIVE VIEWS OF THAI EFL LEARNERS'LEARNING ORAL COMMUNICATION SKILLS. Academic Research International, 1(1), 90.

Koşar, G., \& Bedir, H. (2014). Strategies-based instruction: a means of improving adult EFL learners' speaking skills. International Journal of Language Academy, 2(3), 12-26.

Latif, M. M. M. A. (2017). English Education Policy at the Pre-university Stages in Egypt: Past, Present and Future Directions. In English Language Education Policy in the Middle East and North Africa (pp. 33-45). Springer.

Lee, L. (2014). Digital news stories: building language learners' content knowledge and speaking skills. Foreign Language Annals, 47(2), 338-356.

Lin, J. M.-C., \& Wu, Y.-J. (2010). Netbooks in sixth-grade English language classrooms. Australasian Journal of Educational Technology, 26(7).

Lindsay, G., Dockrell, J., Desforges, M., Law, J., \& Peacey, N. (2010). Meeting the needs of children and young people with speech, language and communication difficulties. International Journal of Language \& Communication Disorders, 45(4), 448-460.

López-Torrijo, M., \& Mengual-Andrés, S. (2015). An Attack on Inclusive Education in Secondary Education. Limitations in Initial Teacher Training in Spain. Journal of New Approaches in Educational Research, 4(1), 9.

Lucarevschi, C. (2016). The role of storytelling on language learning: A literature review. Working Papers of the Linguistics Circle. Retrieved from https://mmduvic.ca/index.php/WPLC/article/view/15309

Mcquiggan, S. W., Rowe, J. P., Lee, S., \& Lester, J. C. (2008). Story-based learning: The impact of narrative on learning experiences and outcomes. In International Conference on Intelligent Tutoring Systems (pp. 530-539). Springer.

Mostafa, M. K. I. (2017). The Effect of Chants and Short Stories on Primary Stage Pupils' Communication and Attitudes. World Journal of Educational Psychology, 1(doi: 10.11), pp-1.

Normann, A. (2011). Digital Storytelling in Second Language Learning. Faculty of Social Sciences and Technology Management, 125. Retrieved from ntnu.divaportal.org/smash/record.jsf?pid=diva2:445952

Norrick, N. R. (2000). Conversational narrative: Storytelling in everyday talk (Vol. 203). John Benjamins Publishing.

Ono, Y. (2014). Motivational effects of digital storytelling on Japanese EFL learners. Proceedings of CLaSIC, 414-431. 
Patil, Z. N. (2008). Rethinking the objectives of teaching English in Asia. Asian EFL Journal, 10(4), 227-240.

Primary National Strategies. (2009). Developing language in the primary school : Literacy and primary languages.

Raghavendra, P., Olsson, C., Sampson, J., Mcinerney, R., \& Connell, T. (2012). School participation and social networks of children with complex communication needs, physical disabilities, and typically developing peers. Augmentative and Alternative Communication, 28(1), 33-43.

Razmi, M., Pourali, S., \& Nozad, S. (2014). Digital Storytelling in EFL Classroom (Oral Presentation of the Story): A Pathway to Improve Oral Production. Procedia - Social and Behavioral Sciences, 98(2011), 1541-1544. https://doi.org/10.1016/i.sbspro.2014.03.576

Razmjoo, S. A., \& GHASEMI, A. S. (2011). A model of speaking strategies for EFL learners.

Ripley, J. (2015). Watching Storytelling: Visual Information in Oral Narratives, (October), 895.

Rohmah, Z. (2012). Incorporating islamic messages in the english teaching in the indonesian context. International Journal of Science \& Education, 2(2), 2223-4934.

Salmon, C. (2017). Storytelling: bewitching the modern mind. Verso Books.

Schady, N. (2011). Parents' education, mothers' vocabulary, and cognitive development in early childhood: Longitudinal evidence from Ecuador. American Journal of Public Health, 101(12), 2299-2307.

Shiel, G., Cregan, Á., McGough, A., \& Archer, P. (2012). Oral language in early childhood and primary education (3-8 years). Dublin: National Council for.

Siemens, G. (2014). Connectivism: A Learning Theory for the Digital Age. International Journal of Instructional Technology and Distance Learning, 1, 1-8. https://doi.org/10.1.1.87.3793

Smeda, N. (2014). Creating Constructivist Learning Environments with Digital Storytelling, 1-255.

Smeda, N., Dakich, E., \& Sharda, N. (2014). The effectiveness of digital storytelling in the classrooms : a comprehensive study, 1-21. https://doi.org/10.1186/s40561-014-0006-3

Songsiri, M. (2007). An Action Research Study of Promoting Students' Confidence in Speaking English, (March).

Swan, K., \& Hofer, M. (2013). Examining student-created documentaries as a mechanism for engaging students in authentic intellectual work. Theory \& Research in Social Education, 41(1), $133-175$

Tatum, M. E. M. (2009). Digital storytelling as a cultural-historical activity: Effects on information text comprehension.

Thapa, A., Cohen, J., Guffey, S., \& Higgins-D’Alessandro, A. (2013). A review of school climate research. Review of Educational Research, 83(3), 357-385.

Tsou, W., Wang, W., \& Tzeng, Y. (2006). Applying a multimedia storytelling website in foreign language learning. Computers \& Education, 47(1), 17-28.

Vinogradova, P., Linville, H. A., \& Bickel, B. (2011). "Listen to My Story and You Will Know Me": Digital Stories as Student-Centered Collaborative Projects. TESOL Journal, 2(2), 173-202. 
The Effect of Utilizing Digital Storytelling on Developing Oral Communication Skills for 5th Grade Students at Rafah Primary Schools

Werner, R. J. (2011). Self-Access and Metacognitive Awareness in Young Learners: How Japanese Sixth Graders Learn How to Learn English. Reading.

Widodo, H. P. (2016b). Engaging young learners of English in a genre-based digital storytelling project, (March). Retrieved from http://languageresearch.cambridge.org/images/pdf/201516 Widodo CUP TRP final report.pdf

Yelland, N., Lee, L., \& O’Rourke, M. (2008). Rethinking learning in early childhood education. McGraw-Hill Education (UK).

Ying, L. (2012). A tool for using the control of character animation to help teach children communication skills. University of Nottingham, (April), 1-248. Retrieved from http://etheses.nottingham.ac.uk/2692/ 